UNRAM Law Review is licensed under a Creative Commons Attribution 4.0 International License, which permits unrestricted use, distribution, and reproduction in any medium, provided the original work is properly cited. p-ISSN: 2548-9267 | e-ISSN : 2549-2365, Open Access at : http://unramlawreview.unram.ac.id/index.php/ulr

\begin{tabular}{c|c|c|c|c|}
\hline Volume & Issue & Page & October & p-ISSN: 2548-9267 \\
4 & 2 & $153-162$ & 2020 & e-ISSN : 2549-2365
\end{tabular}

\title{
The Making of Land Deed and the Registration of Land Rights Transition through the Inheritance by the Village Community and its Legal Implications (A Study in Sub District of Lingsar, the District of East Lombok)
}

\author{
Arba \\ Faculty of Law Mataram University \\ Email: arba2017@unram.ac.id \\ Sahnan \\ Faculty of Law Mataram University \\ Email: sahnan_mih@yahoo.co.id
}

\begin{abstract}
The aims of this research are to review and analyzing the society behavior in making of the land deed and the registration of land transition on the transfer of rights through inheritance, and its legal implications if the transfer of the land rights without the land deed and was not registered in the national land agency. The study of this research is empirical legal studies and using the normative approach as well the sociolegal approach. Which are the library conduct and the data from the field, the result of this research reviewed and analyzed in the normative and qualitative ways.The normative analysis using the legal interpretation while the qualitative analysis using the data reviews. Further, it is concluded through the deductive reasoning and the result of this research after reviewed and analyzed are as follows: 1. the reason of the society in sub district of Lingsar tend to not make the land deed and did not do the registration in the national land agency on the matters of transfer of land rights are: the heritance custom, the legal tradition of the society have been rooted, the registration needs a lot of money to spend, and the procedures of land deed making and its registration takes a long period of time. 2. The legal implication of land rights through inheritance which was not registered and the deed was not made is legitimate and is protected under the law, since the heritance is the legal event which according to the law where the rights of inheritance land is transferred, the making of deed and registration only as the administration obligations.
\end{abstract}

Keywords: the land deed; registration; the transfer of inheritance rights.

\section{INTRODUCTION}

Thetransfer of rights of a land may be done during life and may be transfer when the testator passed away. The transfer of rights of a land may be done through the legal action and the legal event. The transfer of rights of a land through a legal event is inheritance.

Under the Islamic concept, inheritance may be done after the testator passed away however according to the practice of customary law society, the implementation of inheritance may be obtain before the testator passed away through a legal action which called "hibah" (grants). The transfer of rights through grants may be done based on the 
agreements of the heirs' party, believing each other, and helping each other according to the tradition or customary law of the society. The customary law principle in transferring the land rights must be clear and cash. The cash (without the terms) means that the heir hand out his own properties in the amount which have been agreed (in cash), while the acceptor will directly receive his inheritance object. Clear means that the transfer of rights must be done in front of the official authority and witnesses by several bystander. ${ }^{1}$ This is means that in the customary society does not need a formal legal action in the written form.

The national agrarian law of the act number 5 the year 1960 concerning the basic rules of Agrarian (in short terms known as UUPA), at its one main purposes is to guarantee the certainty of law and rights for the rights holder which require the government and every person who owns the land rights to registered as mentions under article 19, 23, 32, and 38 . Further regulated with the government regulation number 10 the year 1961 concerning the land registration which then replace with government regulation number 24 the year 1997 concerning the land registration.Both of the regulations instructed that every transfer of land rights is required to be registered, and every land registration must be included the deed of transfer of rights.

Article 19 of the government regulation number 10 the year 1961 stated that every agreement which made in means to transfer the land rights, provides a new legal rights of a land, mortgaged the land or lending a money with the rights of a land as the dependent, must be proved with a deed which made in front of the official who pointed by the agrarian ministry (hereinafter under this government regulation called as: officials). Article 20 mentions that: (1) if a person who has the land rights passed away, so the acceptor of the land which is inheritance must be asking for the registration of transfer of land rights in a period of 6 month since he is passed away. (2) The ministry of agrarian or official which was pointed by him may be extend the time on the article (1) of this articles according to particular consideration.

Furthermore, under article 37 of the government regulation number 24 the year 1997 specify: (1) the transfer of land rights and ownership of apartment through buy and sell, exchange, grants, an income to the company and legal action of other transfer kinds, except of the transfer through auction. Only able to be registered, if it is proved with the deed which made by the land deed official who has the authority by virtue of the applicable laws. (2) under a specific circumstances as regulated by the ministry, head of land office may registered the transfer of land rights and ownership, which is done between individuals of Indonesian citizen that is proved with the deed which made by the official land deed, however according to the head of land offices the truth level is considers enough to do the rights registration.

According to the regulation above, it is clear that every transfer of the land rights in any form of the legal action and legal action which cause the transfer of land rights must be made of the deed and registered to the land agency. Therefore, the main purpose of the land registration is to guarantee the law certainty and the rights of a land. The legal certainty including: a. the legal certainty of the land as its object, which is the parcel area of a land, the lies of the boundary and the breadth (the rights object); $b$. the legal certainty of the subject rights which is who is the owner (rights subject); and c. the legal certainty of the typed of land rights. ${ }^{2}$ The

\footnotetext{
${ }^{1}$ J. Kartini Soedjendro. (2001). Perjanjian Peralihan Hak Atas Tanah Yang Berpotensi Konflik, Yogyakarta: Kanisius, p. 49.

2 Arba, HM. (2015). Hukum Agraria Indonesia (cetakan 1). Jakarta:Sinar Grafika, p. 153.
} 
legal certainty in essence is the main purpose of the law. The regularity of society has a strong relation with the certainty of the law, because the regularity is the core of this certainty, and so from this the regularity will impact to the people live in certainty in performing what is need in the society circumstances.

According to the statement by SudiknoMertokusumo the legal certainty is a guarantee that the law must be perform in well manner. The certainty wants the existence of legal regulatory efforts which made by the official and prestigious authorities, so that the regulation will have the juridical aspect which able to guarantee the existence of certainty of the law which is the law in its function as regulation that must be obey. ${ }^{3}$

Law is made by the society to regulated, organize and protect the rights and ruled the obligation of everyone. Every human being in their lives has the rights and obligation which is required to be obtain, obey, and respect and protect. Roscoe Pound which cited by SoerjonoSoekanto stated that the concept of legal functions as a tool of social engineering. The understanding of legal function as a tool of social engineering is a law as a tool to change the society in means that law may be used as an agent of change. The agent of change is someone of a group of people which obtain the trust from society as a leader or more the agencies of the society. ${ }^{4}$

In contrast with the law regulation and the legal theory above, then law will try to provide certain guarantee and protection to the society in terms of legal action or even in the legal relation and legal action. Law under the above concpet is a wrtten law which made by the official authority according to the regulation.

However in the practice in the customary society in ditsrcit of Lingsar. Through our reserach shows that in general, they tend to not make the land deed and do the registration of land rights which resulted from inheritance. This matter have been become their tradition hereditary which have been institutionalize (customary law).

In order to analyse this reality, under this research also using the theory of legal efectivity to undertsad the fatcors which causes the innevectiveness of this legal rules in the society.

Lawrance M. Freidmann views the laws as a system which contains of structural components, substantive and cultural, so the legal function as a direct tool of social engineering and actively imposes the change in society. ${ }^{5}$ Soerjono Soekanto stated that there are several factors which affects the affectivity of legal rules, which are: ${ }^{6}$

1. The legal rules (law)

2. The law enforcer

3. The facilities and infrastructure

4. The society

According to the descriptions above it can be formulated several main problems in this research as follows:

\footnotetext{
${ }^{3}$ Satjipto Rahardjo. (2000). Ilmu Hukum. Bandung: PT. Citra Aditiya. p. 253.

${ }^{4}$ Roscoe Pound. (1972). Pengantar Filsafat Hukum. cited in Soerjono Soekanto. (1997). Pengantar Sosiologi Hukum. Jakarta: Bhratara, P.104-105.

${ }^{5}$ Lawrance M. Freidmann dalam Esmi Warassih Pujirahayu. (2011). Pengaruh Budaya Hukum Terhadap Fungsi Hukum, Semarang: Badan Penerbit Universitas Diponegoro, p. 134.

${ }^{6}$ Soerjono Soekanto. (2008). Yang Mempengaruhi Faktor-faktor Penegakan Hukum, Jakarta: PT. Raja Grafindo Persada, p. 5 .
} 
1. Why doesthe society district of Lingsar in the matter of transfer of land rights through inheritance did not made the land deed and did not do the registration in the land agency?

2. What is the legal implication of the unregister land rights which obtain from inheritance and exist without the land deed?

\section{METHOD}

This research is empirical research which is a legal research that reveals and analyze the implementation of legal norms which are written and unwritten in the rural society life which related with the transfer of a land rights through inheritance. The approach of this research using statute approach, conceptual approach, and historical approach while the empirical approach is social approach and cultural approach.

The legal materials conducted through the library research while the data comes from field research. The legal materials contains of primary legal materials such as regulation, and secondary legal materials such as concept of theory and the statement of expert, and the result of research and tertiary legal materials such as dictionaries and legal dictionary. Whilst the field data contains of primary data resourced from the respondent and informant, and secondary data resources from official documents in the field.

The legal materials collected through a study of documents and analyzed the library resource with legal interpretation also analyze the literature. The conduct of the field data was done through a direct interview with the respondent and informant. The respondent is the society member which have performed the legal action of inheritance of a land rights, while the informant who have been interviewed is the head of village and land deed official also the land agency.

Checking the validity of the data done through a triangulation technic. Triangulationaccording to S. Nasution is that a data or information from one party should be check its correctness through the data of other resource, for example from the second, the third party and so on by using the different method. The purpose is to compare the same information which collected from any parties in order to guarantee the level of the truth of the data. ${ }^{7}$

\section{ANALYSIS AND DISCUSSION}

\section{The Transfer of Land Rights through Inheritance in the Society of the Sub District of Lingsar}

Theresult of the research shows that in the rural society in the district of Lingsar, generally the inheritance performed in two ways, which is legal event (the death of the testator) and through the legal action of grants. Both of this matters, done through the customary law and the religious law of the society, so that both of the legal event and action are done based on the religious law and customary law. Both of this law does not required the official legal action in order to be legalize. The customary law mentions that the transfer of a rights of a land even its transition performed based on the society custom which is orally and witnessed by the relatives and family members and followed with a real handover.

\footnotetext{
${ }^{7}$ S. Nasution. (1986). Penelitian Kualitatif-Naturalitik. Bandung: Tarsito, p.126.
} 
From the thirty (30) respondent who was interviewed at random in the three sample villages, which is Duman Village, Lingsar Village, and Karangbayan Village of the district of Lingsar it pictured the implementation of the transfer of a land rights through inheritance as follows:

Tabel 1. The interview result with respondents

\begin{tabular}{rrrrrrr}
\hline \multirow{2}{*}{ No } & $\begin{array}{r}\text { The } \\
\text { sample }\end{array}$ & $\begin{array}{r}\text { The } \\
\text { amounf of } \\
\text { villages }\end{array}$ & Orally & under & & Written \\
respondent & & & UPPA & orally & Written \\
\hline 1 & Duman & 10 & 8 & 2 & $80 \%$ & $20 \%$ \\
\hline 2 & Lingsar & 10 & 7 & 3 & $70 \%$ & $30 \%$ \\
\hline 3 & Karang Bayan & 10 & 9 & 1 & $90 \%$ & $10 \%$ \\
\hline 4 & Jumlah & 30 & 24 & 6 & $80 \%$ & $20 \%$ \\
\hline
\end{tabular}

The data resource: the primary data processed

According to the table data above, describes the comparison of respondent which performed the inheritance legal action of a land rights through oral (customary law) with the written inheritance legal action according to the regulation under agrarian act. The percentage above shows the trend of splitting the inheritance rights of a land performed orally according to the forum and agreement of the heirs. The society who divide the inheritance by written only as the unofficial deed which made by the heirs and witnessed by the head of the village or the community leaders.

This reality supported by the statement of a notary and official land deed in the sub district area of Lingsar in the official area the district of east Lombok "Syahril Marta Azis who stated that it's been 3 years he become a notary and official land in the sub district of Lingsarand for this terms of time he have not been made the deed of land rights transfer through inheritance. The deed which he only made was only the division deed of joining property.

The reason on why the society do not perform the deed of transfer of land rights through inheritance and not perform deed registration in the land agency will be mentions as follows:

1. The tradition and customary law of the society

2. The legal tradition of the society

3. The economic reason/cost

4. The time in processing the registration take a long time.

The Descriptions:

1. The tradition or customary law of the society; the transfer of inheritance land rights in sub district of Lingsar, generally it does not need the written legal action through an official deed or authentic deed, it is enough ti be done orally based on the agreement of the heirs and witnessed by the family or community leaders. Even if it performed in written it still unofficial deed which made with signature of the heirs and witnessed by the community leaders.

2. The legal tradition of the society

What it means by the legal tradition of the society is a tradition and the behavior of the community which continuously lives in the community. The society considers that everything which has been done by the ancestor as a good thing and constantly to be maintain as long as it is generating peace in the society. 
3. The economic reason/cost; the made of transfer of land rights and the transition registration of deed need a big amount of money. For this reason the rural society which majority work as a farmer and lack in education tend to get the rights of a land according to the custom of the ancestor. The community will have the registration of inheritance land rights if there is a systemic land registration from the government with the state cost.

4. The registration process takes too much time; this is the main reason why the community does not want to transfer the inheritance land deed and the registration.

According to the factors which mentions above if it analyzes through the legal efectivity theory from SoerjonoSoekanto who stated that there are several factors which affect a regulation, which is: ${ }^{8}$

1. The rule themselves (law);

2. The law enforces

3. Facilities and infrastructure

4. The society;

5. Custom

The fifth factors related with the research above, which is the reason on why the legal norms above does not applicable are causes by two main factors which is the customary law (custom/tradition) which held continuously, and the legal custom of the society. While the economic factor and the long time process only as the addition factors.

Inheritance is one of the transfer of a land rights way which occurred from the testator to the heir. An inheritance legally transfer if the testator passed away, however the inheritance may be switch on his life through a grants, which next that part as his inheritance part.

As a legal event, the inheritance delivered a new legal rights for the heir, likewise with the legal action of inheritance through grants which resulted the birth of a new rights for the grantee or the heir who accept the grants. Both of this legal event and action causes the transfer of inheritance to the heirs.

Every legal events and action of the transfer of a land rights arise a legal implication to the legal subject, so for this it will needs the certainty of the law for the parties and even the land as its object. The guarantee of law certainty in purpose to protect the rights of the parties and identified the obligation of each party. The law ordered and obligated that every legal action and events that has the purpose to transfer the land rights required to be registered and every registration must be proved with a deed.

Sudikno Mertukusumo stated that the law certainty is a guarantee that the law must be obtain in a good manner. The certainty of the law wants the existence of an effort on regulation under the law which made by the official who have the authority and prestigious, so that the provision will have the juridical aspect which is able to guarantee the law certainty in function as a regulation that must to obey. ${ }^{9}$

Therefore, according to Article 37 of the government regulation number 24 the year 1997 which determines that: (1) the transfer of the land rights and ownership of an apartment through sale and buy, exchange, grants, a company income and legal actions of any other transfer of rights, except for the rights transfer through an auction, only able to be registered, if it is proved with the deed which made by the land deed official who has the authority according to

\footnotetext{
${ }^{8}$ Soerjono Soekanto. (2008). Faktor-faktor Yang Mempengaruhi Penegakan Hukum, Jakarta: PT. Raja Grafindo Persada. p. 5.

${ }^{9}$ Mertokusumo Sudikno, Loc, Cit, p. 16.
} 
the applicable law. (2) in particular circumstances as mention by the ministry, head office of the land may be registered the transfer of the land rights, which is performed by an individual of Indonesian citizen which proved with deed that made in the official land deed, however according to the land head office the level of the truth considers enough to be registered on the transfer of rights of the concern subject.

Further, article 38 also determines the made of deed as mentions under article 37 paragraph (1) which attended by the parties who did the legal action and witnessed by at least of two witnesses who satisfy the requirements to be a witness on the legal action.

The making of a land deed and registration of land rights is be understanding in order to manifest the purpose of the national agrarian law (UUPA) which is to provides law certainty for the rights holder. The law formed to protect the rights and obligation of the society, nation and state. The law function to provide protection and guidance for everyone in the nationality and patriotic. The legal function according to Hoebel concluded as follows: ${ }^{10}$

1. Establish the relations between the community, by showing the kind of behaviour which one is allowed and prohibited.

2. Establish the divison of power, and detailing of who is legally inforce and who will obey also choosing the effective and right penalty.

3. Resolving dispute

4. Maintain the society capability to adapt with the life conditions that change, in a way to formulated again the relations between the communities member.

Analysing the legal function acording to Hobel, the legal order is to do everything in the applicable legal way in effort to guarantee the legal relation between the communities, determines the duty and responisbility of each legal subject, in means for every problem that they faced may be solved in the principles of forum and certainty. Other than that, concerning the development of society behaviour which always developed together with the globalisation, then the certainty of the law and the portection forthe rights of legal subject on an object which they controlled and owned is very important.

This is not menas that the customary law denied. The customary law as one of positive law which applicable in the society that continuosly and rooted in the sould of the community needs to be protect, respected, and enforced according to the community interest and legal interest of the state also cannot be denied.

\section{The legal implication of the rights of a land through ineritance without the making of the land deed and is not registered in the land agency}

Unwritten law or called as customary law even the written law as the regulation is a law which lives in the society which become basic guidance for the community lifes. Both if this legal rules become the law resource and base for the communities to do the legal action or legal event. Both of these law guarantees the life together of the community members which regulated, well laid out, honest and fair.

The transfer of land rights through inheritance as the legal action and legal event done according to the norms and regulation which lives whether in the wrotten or unwritten forms.

${ }^{10}$ Edwin M. Schur. (1968). Law and Society: A Sociological View. New York: Random House, p. $79-82$ (kf. Djasadin Saragih (Trnaslator), see also in the Esmi Warassih, Pranata Hukum: Sebuah Telaah Sosiologis, edited byKarolus Kopong Medan da nMahmotarom HR (2005). Semarang: PT. Suryandaru Utama. p. 2627. 
A customary law (Sasak customary law), generally recognize that a legal action or event is a real action which done by the parties that is need to be repsected and appreciated, whetehr for his own party or even other person.

A written law also regulated clearly concerning the provision and the proceduresof a transfer of land rights as mentions under the agrarian law under artcile 23 which stated that: (1) the rights of ownership, also in every transfer, vanish and a burden of other rights must be registered according to the regulation as mentions under Artcile 19. (2) the registration as mentions in paragraph 1 is a prove tools that is strong concerning the vanished of ownership rights also the legality of the transfer and the burden of the rights. Article 36 and 37 of the government regulation number 24 the year 1997 determines: every legal action which has the purpose to transfer the rights of a land is required to be registered, and every registration must be making the land deed. Article 37 stated: (1) the transfer of a land rights and ownership rights of an apartment through buy and selling, exchange, grants, the corporate income and other legal action of other rights transfer, except for the auction, only able to be registered if it is proved with the deed which made by the land deed official who has the authority according to the applicable law. However, under the agrarian law, according to the article 56 mentions the acknowledgement of the existence of rights of customary law as long as if its not formed yet the act concerning ownership rights. It is means the customary ownership rights together with the law which ruled it, whether in the acquisition even the transfer is recognized and legitimate.

The legal action of the transfer of the land rights raises the implications for the parties. The legal impication which sprung up by the legal action or event which is done unilaterally or by the parties which causes the guarantee of law certainty or uncertainty of the law, or even null and void or can be cancelled.Consequently, Sudikno Mertokusumo explained the certainty of the law as a law which needs to be done in a good manner, where a certainty of the law require the effort on forming the regulation by the authorized and prestigious official, so that the regulation has a juridical aspect which able to guarantee the certainty of the law that a function of the law as a rules that must be obey. ${ }^{11}$ The certainty of the law according to Gustav Radbruch, there are two understanding of it which is the certainty of a law by the law and the certainty of the law in a law or from the law. The law which is success in guarantee its certainty in the society is useful law. ${ }^{12}$

According to the definition above, so that the certainty of the law that it means is a guarantee from the law that a legal action and event has the legitimate implication, whether if it strong or not, of the legal action or event in front of the law. The law that is means actually is not only a written law but also including unwritten law. A legal action is legitimate and protected by the law as long the action fulfill the subjective and objective requirements, and performed with good faith, it is not against the decency and propriety. While the legal event such as an inheritance actually does not need the requirements as the legal action, since the legal event is an event which is sudden and is not planned, however it is causes a legal implication, such as the dead of the testator which automatically causes the transfer of the inheritance for the law to the heirs.

According to this matter, then the transfer of the land rights through inheritance which is performed without the make of deed of transfer and registration of the land rights is determines

\footnotetext{
${ }^{11}$ Mertokusumo, Sudikno, Loc. Cit. p. 16.

${ }^{12}$ Gustav Radbruch dalam Mertokusumo,Sudikno, Loc.Cit, p. 16.
} 
legitimate and protected by the law. The legal action on making the transfer deed and the registration on rights transfer is not the legitimate requirements of the rights transfer however it is an obligation for the rights holder to do the registration in order to guarantee the certainty of the law and the certainty of the rights.

\section{CONCLUSION}

According to the description above it can be concluded as follows:

1. The reason of the society in the sub district of Lingsar tend to not make the land deed and not registered in the land agency concerning the transfer of the land rights through inheritance are:

a. The tradition/custom which occurred continuously and rooted in the heart of the community

b. The customary law which comes from ancestor and continuously lives in the heart of the society

c. An economic factors, since the making of a land deed and to do the registration of a land rights in the land agency needs a lot of money, while the inheritance is a legal event which naturally for the law become the rights of the heirs.

d. The procedures in making the land deed and registration is complicated (sporadic land registration) so it is take a long time. The community in general do the registration of their land rights through a systematic registration through a Prone/PTSL program.

2. The legal implication of the land rights through inheritance even without the making of the land deed and is not registered in the land agency is legitimate and protected by the law. As the customary law the transfer of the inheritance land rights does not need to be performed in written way,since the agrarian law by virtue of article 56 recognize the existence of customary rights. Inclusive in it the legal actions which related with the customary land rights. However, in order to satisfy the interest of the law of the nation and state in the government effort to protect the citizen, so the state law also must be maintained well and assertive.

The indigenous people and their rights is recognized and respected constitutionally, therefore the indigenous people and government must respect and acknowledge it, whether it is related with institution, the local norms, as well the legal event/action. Considering the occur development, everything needs an authentic prove, in the acquisition, transfer and ownership of the land rights, therefore the society also needs to obey the state regulation in order to gain the certainty of the law and rights according to the state law.

\section{Bibliography}

Books:

Arba, H.M.(2015). Hukum Agraria Indonesia (cetakan I). Jakarta: Sinar Grafika.

Boedi Harsono. (1999). Hukum Agraria Indaonesia, Sejarah Pembentukan Undang-Undang Pokok Agraria, Isi, dan Pelaksanaannya. Jakarta: Djambatan. 
Edwin M. Schur. (1968).Law and Society: A Sociological View (, (kf. Djasadin Saragih sebagai Penerjemah),New York: Random House

Esmi Warassih. (2005). Pranata Hukum: Sebuah Telaah Sosiologis, diedit oleh Karolus Kopong Medan dan Mahmotarom HR. Semarang: PT. Suryandaru Utama,

Mochtar Kusumaatmadja. (1976). Hukum, Masyarakat dan Pembinaan Hukum Nasional, Bandung: Bina Cipta.

Nasution S. (1986). Penelitian Kualitatif-Naturalitik. Bandung: Tarsito

Sudikno Mertokusumo. (2011). Teori Hukum, Cetakanke 1. Yogyakarta: Universitas Atma Jaya.

Satjipto Rahardjo. (2000). Ilmu Hukum. Bandung: PT. Citra Aditiya Bandung.

Soerjono Soekanto. (1984). Pengantar Penelitian Hukum, Universitas Indonesia. Jakarta: Pres. Jakarta.

Soerjono Soekanto. (2008). Faktor-faktor Yang Mempengaruhi Penegakan Hukum. Jakarta: PT. RajaGrafindo Persada.

Pustaka Bahasa. (2003). Departemen Pendidikan Nasional, Kamus Besar Bahasa Indonesia, Edisi ketiga, Jakarta: Balai Pustaka.

\section{Regulation:}

The Constitutional Act of Republic Of Indonesia 1945

The Act number 5 the year 1960 concerning the basic regulation of agrarian law.

The Government Regulation Number 10 the year 1961concerning the registration of a land and replace with the Government Regulation number 24 the year 1997 concerning the land registration. 